\title{
Beef and Forage Production on Contour Fur- rowed Rangeland Interseeded with Alfalfa
}

\author{
R.J. KARTCHNER, J.R. WIGHT, J.L. BISHOP, AND R.A. BELLOWS
}

\begin{abstract}
Over a 4-year period, average annual herbage production on native range was $603 \mathrm{~kg} / \mathrm{ha}$ compared to $1,350 \mathrm{~kg} / \mathrm{ha}$ on contourfurrowed range interseeded with alfalfa. Addition of $112 \mathrm{~kg} \mathrm{~N} / \mathrm{ha}$ and $15 \mathrm{~kg} \mathrm{P} / \mathrm{ha}$ on furrowed, interseeded range increased herbage production to $1,658 \mathrm{~kg} / \mathrm{ha}$. Forage production on furrowed areas showed more variation in response to precipitation changes than did production on untreated rangeland. Differences in rate of gain by yearling cattle were small in most years, indicating beef production varied largely as a function of stocking rate. Total beef production over a 5-year period was $113 \mathrm{~kg} / \mathrm{ha}$ on the control, 217 $\mathrm{kg} / \mathrm{ha}$ on contour-furrowed range with alfalfa interseeded, and 236 $\mathrm{kg} / \mathrm{ha}$ on furrowed, interseeded range receiving fertilizer. Observations on management of furrowed, interseeded areas were made.
\end{abstract}

Contour furrowing has effectively increased water infiltration (Neff 1973, Neff and Wight 1977), ameliorated physical and chemical characteristics of panspot (Solonetzic) soils (Soiseth et al. 1974), and increased production of native forage species (Neff and Wight 1977, Wight et al. 1978a). It is also an effective means for introducing improved native and introduced forage species, including legumes, into established native vegetation (Wight et al. 1978b). The use of legumes has the potential for not only increasing forage production but, through symbiotic nitrogen $(\mathrm{N})$ fixation, to offset the inherent $\mathbf{N}$ deficit that exists on most western rangelands (Wight 1976). Ultimately, however, the usefulness of a range improvement practice such as contour furrowing must be evaluated under grazing conditions and related to animal performance and production. This study was designed to measure forage production, animal response, and total beef production on rangeland contour furrowed and interseeded with alfalfa, with or without added $\mathrm{N}$ and phosphorus ( $\mathrm{P})$.

\section{Materials and Methods}

Three 16-ha pastures on a semiarid, upland, medium-textured range site near Miles City, Mont., were used in the study. One pasture served as a control, and 2 were contour furrowed and interseeded with Ladak alfalfa (Medicago sativa). The contour furrows were constructed with a lister-type shovel (Fig. 1), which formed flat-bottomed furrows approximately $60 \mathrm{~cm}$ wide and 5 to $12 \mathrm{~cm}$ deep at 1.5 - to 1.8 -m intervals (Fig. 2). Short intrafurrow dams of undisturbed sod, about $1 \mathrm{~m}$ long, were created by lifting the shovels out of the ground at 6- to 9-m intervals. These dams helped compensate for deviations from the contour that could eventually cause water impounded in the furrows to accumulate into an erosive volume.

\footnotetext{
Kartchner and Bellows are research animal scientists, USDA, Agricultural Research Service, Miles City, Mont. 59301; Wight is a range scientist, USDA, ARS, Research Service, Miles City, Mont. 59301 ; Wight is a range scientist, USDA, ARS,
Boise, Idaho 8370 1; Bishop is Director of Agricultural Resources, Burlington Northern, Inc., Miles City, Mont. 59301.

This report is a contribution from the USDA, Agricultural Research Service, in cooperation with Montana Agricultural Experiment Station, Journal Series No. 1227. This paper is a contribution to Western Regional Project W-151.

Sincere appreciation is expressed to Burlington Northern, Inc. for providing land, facilities, livestock, manpower, and financial support for the conduct of this research.

Manuscript received November 21,1981
}

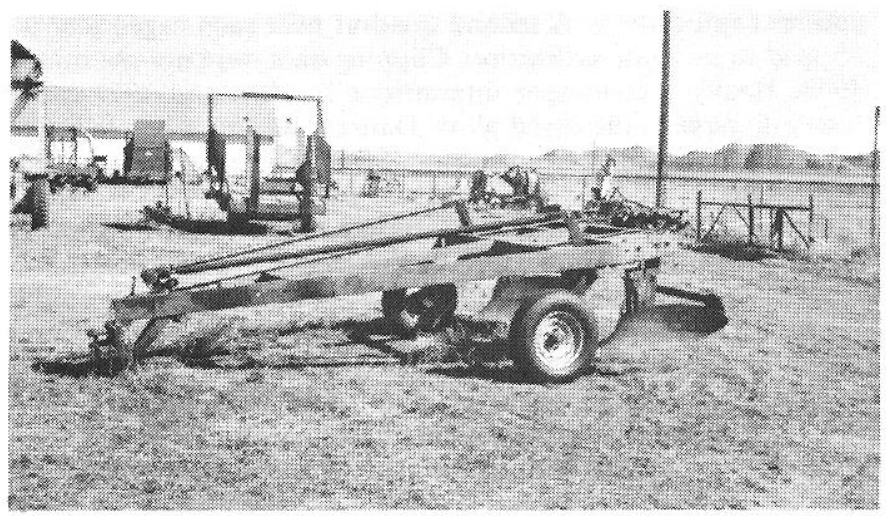

Fig. 1. Furrowing equipment used to construct contour furrows.

Alfalfa was seeded into the furrows at a rate of $2.24 \mathrm{~kg} / \mathrm{ha}$ with a furrower-attached seeder. One treatment consisted only of contour furrowing with alfalfa interseeded (CFA). The second furrowed pasture also received a single application of pelleted ammonium phosphate supplying $112 \mathrm{~kg} \mathrm{~N} / \mathrm{ha}$ and $15 \mathrm{~kg} \mathrm{P} / \mathrm{ha}(\mathrm{CFAF})$. A third untreated native range pasture served as a control. Dominant forage species in this a rea included western wheatgrass (Agropyron smithii), needleandthread grass (Stipa comata), blue grama (Bouteloua gracilis), and buffalograss (Buchloe dactyloides). Big sagebrush (Artemesia tridentata wyomingensis) was found in isolated pockets. A watering tank was located in the corner of each pasture for livestock use, and salt was available at all times.

Furrowing, seeding, and fertilizer treatments were applied in the spring of 1973, and grazing commenced in the spring of 1974. Pastures were grazed by a combination of yearling heifers and steers in 1974 , by yearling steers in 1975 , and by yearling heifers in 1976, 1977, and 1978.

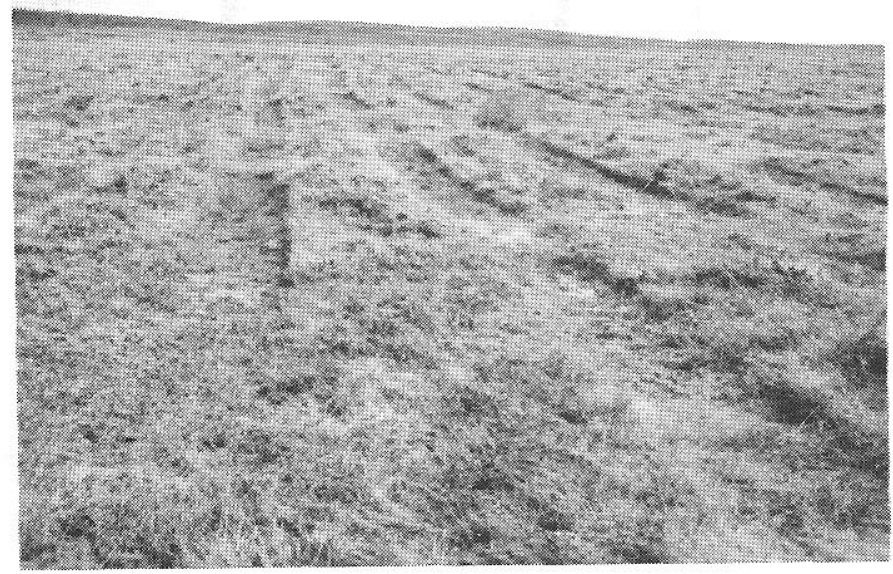

Fig. 2. Contour furrows 3 years after treatment application. 
Pastures were stocked at levels calculated to provide equal forage utilization over a 60 -day grazing period. Initially, grazing capacity was estimated for the control pasture using Soil Conservation Service condition class guidelines (U.S. Department of Agriculture 1971) and on contour-furrowed pastures from clipping data obtained from previously established contour-furrowing work (Neff and Wight 1977).

Cattle were weighed onto the pastures in mid- to late May and grazing continued until an estimated $50 \%$ utilization was achieved at which time cattle were weighed off pasture. Cattle were removed from all pastures at the same time. A mid-period weight was obtained in 1976, 1977, and 1978.

Forage production was determined on 6 caged plots in each pasture. Within each caged area, a 0.5 - by $2-\mathrm{m}$ quadrat was handclipped at ground level and separated by species at approximately peak standing crop. Dried sample weights were used to determine species composition. A second quadrat near each caged plot was clipped to estimate utilization. Clipping data were not obtained in 1974. Heavy grasshopper infestations in 1976 and 1977 caused heavy da mage to the caged plots. Damage was most severe in 1976 in terms of being able to accurately estimate forage production and utilization.

A Soil Conservation Service survey of the experimental area prior to treatment application determined that the vegetation on the 3 pastures was largely homogeneous and productive potential for the 3 areas was similar. Therefore, it was assumed that differences in forage production following treatment application were due to the treatments, not inherent pasture differences. Forage production data were analyzed as a completely randomized design with 6 plots or observations per treatment. Treatment means were separated by multiple range comparisons. Animal gain data were analyzed as a completely randomized design using individual animal performance as the unit of observation. Differences in gain between sexes in 1974 were not significant so gain data were pooled within treatments. The LSD test for unequal subclass numbers was used for treatment comparisons (Steel and Torrie 1960).

\section{Results and Discussion}

Precipitation received during the period of the study is shown in
Figure 3. Mean annual precipitation for the area from 1941 to 1970 was $34.4 \mathrm{~cm}$ (U.S. Department of Commerce 1979). Total precipitation equalled or exceeded this amount for each year of the study except 1976. However, forage production (Table 1) was more closely related to precipitation received during the principal growing months of April, May, and June than to total annual precipitation. Mean annual precipitation for April-June was $14.7 \mathrm{~cm}$ for the period 1940-1972 (Caprio et al. 1980). During this 3-month period, 1975 and 1978 had above average precipitation and 1976 and 1977 were below average.

The greatest total forage production was recorded in 1975, followed by 1978, the 2 years of above-average April-June precipitation. Furrowed areas had the benefit of added nutrient a vaila bility in 1975 from decaying organic matter resulting from the furrowing process (Wight et al. 1978a). Forage production was lower in 1976 and 1977 as a result of the lower precipitation received during the principal growth period. Clipping data for these 2 years underestimated by an undetermined amount the actual forage production as heavy grasshopper infestations resulted in considerable damage to experimental plots. Alfalfa production estimates were probably least reliable since alfalfa plants appeared to be consumed by grasshoppers in preference to native species.

In the 2 years with above-average precipitation, grass, alfalfa, and total production on the fertilized pasture tended to be greater than on the nonfertilized furrowed area. This was not true in the 2 drier years. Likewise, grass production and total production on furrowed pastures tended to exceed that on the control pasture in 1975 and 1978. Grass production was similar on all treatments in 1976 and 1977, although total production on furrowed areas tended to exceed that of the control. Alfalfa production was relatively high in 1975 but dropped considerably in 1976 where it remained relatively constant through 1978 .

As a percentage of the total forage (Table 2), alfalfa remained relatively constant until 1978 , when it dropped d ra matically. This was attributable to the alfalfa production remaining constant, whereas grass production increased from two- to four-fold from 1977 to 1978.

Shrubs were not present on the plots in the control pasture and contributed less than $1 \%$ to the plant community on the two

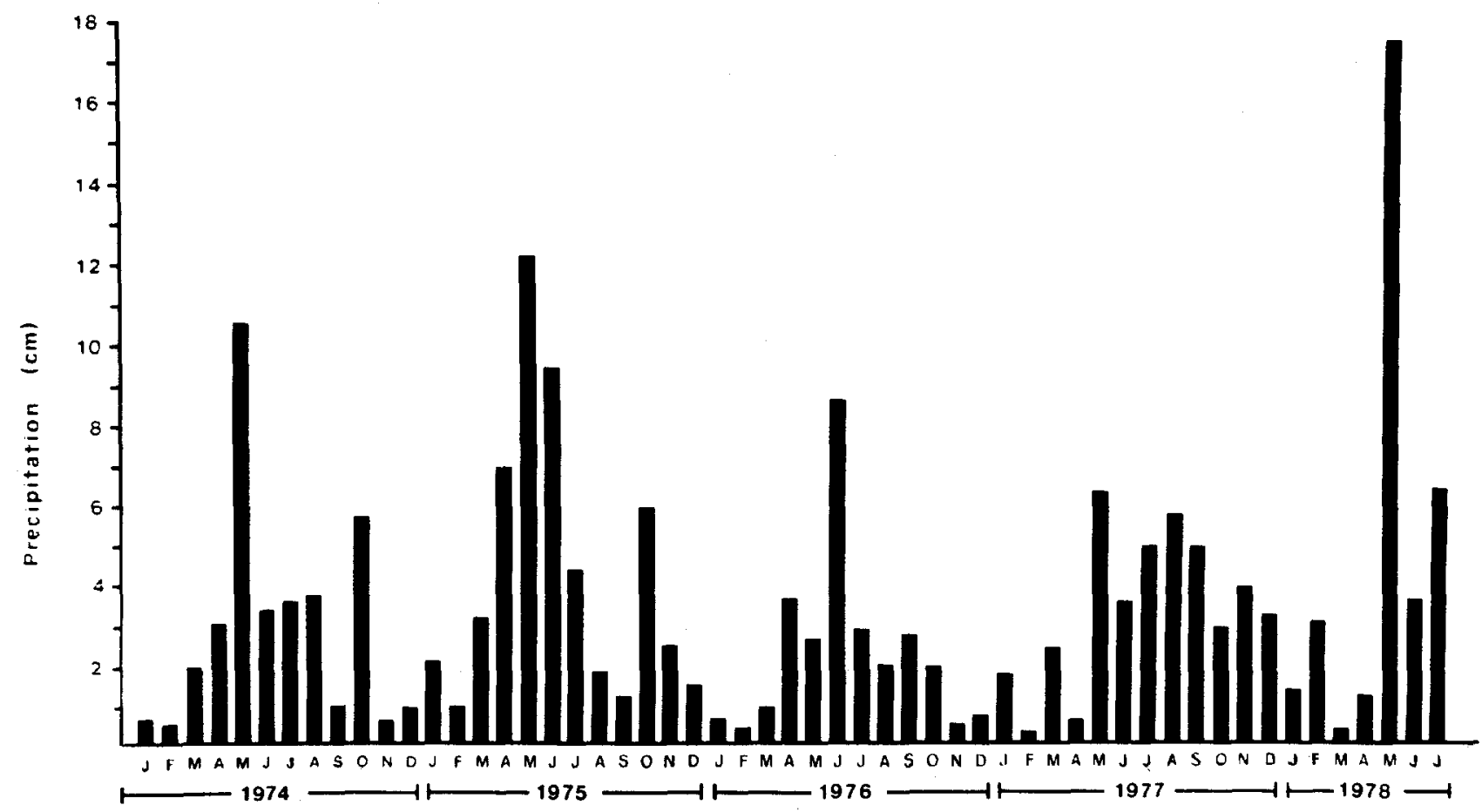

Fig. 3. Monthly precipitation for the experimental period. 
Table 1. Production of forages $(\mathrm{kg} / \mathrm{ha})$ on untreated and contour-furrowed rangeland.

\begin{tabular}{|c|c|c|c|c|c|c|}
\hline \multirow[b]{2}{*}{ Forage class } & \multirow[b]{2}{*}{ Treatment } & \multicolumn{4}{|c|}{ Year } & \multirow[b]{2}{*}{ Mean } \\
\hline & & 1975 & 1976 & 1977 & 1978 & \\
\hline Grasses \& sedges & $\begin{array}{l}\text { Control } \\
\text { CFA } \\
\text { CFAF }\end{array}$ & $\begin{array}{c}729^{\mathrm{b}} \\
1021^{\mathrm{b}, \mathrm{c}} \\
1580^{\mathrm{c}}\end{array}$ & $\begin{array}{l}451^{b} \\
328^{b, c} \\
261^{c}\end{array}$ & $\begin{array}{l}353 \\
444 \\
330\end{array}$ & $\begin{array}{r}779 \\
1058 \\
1448\end{array}$ & $\begin{array}{l}578^{b} \\
713^{b, c} \\
905^{c}\end{array}$ \\
\hline Forbs & $\begin{array}{l}\text { Control } \\
\text { CFA } \\
\text { CFAF }\end{array}$ & $\begin{array}{l}13^{\mathrm{b}} \\
66^{\mathrm{c}} \\
30^{\mathrm{b}, \mathrm{c}}\end{array}$ & $\begin{array}{r}0 \\
14 \\
13\end{array}$ & $\begin{array}{c}1^{\mathrm{b}} \\
39^{\mathrm{c}} \\
15^{\mathrm{b}, \mathrm{c}}\end{array}$ & $\begin{array}{r}87 \\
75 \\
121\end{array}$ & $\begin{array}{l}25 \\
48 \\
45\end{array}$ \\
\hline Shrubs & $\begin{array}{l}\text { Control } \\
\text { CFA } \\
\text { CFAF }\end{array}$ & $\begin{array}{r}0 \\
13 \\
0\end{array}$ & $\begin{array}{l}0 \\
0 \\
0\end{array}$ & $\begin{array}{l}0 \\
0 \\
0\end{array}$ & $\begin{array}{r}0 \\
37 \\
17\end{array}$ & $\begin{array}{r}0 \\
12 \\
4\end{array}$ \\
\hline Alfalfa $^{\mathrm{d}}$ & $\begin{array}{l}\text { Control } \\
\text { CFA } \\
\text { CFAF }\end{array}$ & $\begin{array}{r}0 \\
1077 \\
1582\end{array}$ & $\begin{array}{r}0 \\
483 \\
236\end{array}$ & $\begin{array}{r}0 \\
256 \\
409\end{array}$ & $\begin{array}{r}0 \\
310 \\
591\end{array}$ & $\begin{array}{r}0 \\
532 \\
704\end{array}$ \\
\hline Totals & $\begin{array}{l}\text { Control } \\
\text { CFA } \\
\text { CFAF }\end{array}$ & $\begin{array}{r}742^{b} \\
217 \tau^{c} \\
3192^{c}\end{array}$ & $\begin{array}{l}451^{\mathrm{b}} \\
825^{\mathrm{c}} \\
510^{b, c}\end{array}$ & $\begin{array}{l}354^{b} \\
739^{c} \\
754^{c}\end{array}$ & $\begin{array}{c}866^{\mathrm{b}} \\
1480^{\mathrm{b}, \mathrm{c}} \\
2177^{\circ}\end{array}$ & $\begin{array}{r}603^{b} \\
1350^{c} \\
1658^{c}\end{array}$ \\
\hline
\end{tabular}

Control = untreated rangeland; $\mathrm{CFA}=$ contour-furrowed rangeland interseeded with alfalfa; $\mathrm{CFAF}=$ contour-furrowed rangeland interseeded with alfalfa with $112 \mathrm{~kg} \mathrm{~N}$ and $15 \mathrm{~kg} P$ applied per ha.

${ }_{b, c}$ Values within forage class and year with unlike superscripts differ $(P<.05)$.

'All comparisons between CFA and CFAF were nonsignificant $(P>.05)$.

furrowed pastures (Tables 1 and 2). Native forbs generally contributed less than $5 \%$ on each of the pastures. Forage utilization varied among treatments and years. A 4-year average was $45 \%$ for control, $47 \%$ for CFA and $50 \%$ for CFAF.

Average daily gains by yearling cattle were higher $(P<.05)$ on the control pasture than for those on either CFA or CFAF in 1974 (Table 3). Cattle on the CFA pasture gained less $(P<.05)$ than those on the other two treatments in 1975 . In other years, differences in rate of gain were not significant at the $95 \%$ probability level.

The reasons for the marked rate of gain difference in 1974 are now known. The absence of clipping data for that year makes it impossible to determine in retrospect whether the stocking pressure applied on the different treatments matched the available forage resource. Another potential cause for the difference in performance would be the quality of forage avilable. This, too, was not subject to verification. It is possible that animals were put in too late for best forage conditions. In subsequent years, the differences in rate of gain were sufficiently small that beef production per unit area could be largely considered a function of stocking rate.

Beef production values are given in Table 4 . In the first year, each contour-furrowed pasture was grazed by triple the number of animals on the control pasture. However, the lower rate of gain in that year on the CFA and CFAF pastures relative to the control pasture resulted in only a doubling of the beef produced from each of the contour-furrowed pastures as compared to the control. In subsequent years, stocking rates were reduced on the CFA and CFAF pastures to approximately double that for the control pasture. Consequently, beef production on the contour-furrowed pastures remained about twice that of the control pasture-both within years and for the total of the 5 years.

Table 3. A verage daily gain (kg) by cattle grazing native range or contourfurrowed range interseeded with alfalia.

\begin{tabular}{lcrrrr}
\hline \hline & \multicolumn{5}{c}{ Year } \\
\cline { 2 - 6 } Treatment & 1974 & 1975 & 1976 & 1977 & 1978 \\
\hline Control & $1.16^{\mathrm{b} 2}$ & $1.22^{\mathrm{b}}$ & .92 & 1.16 & 1.06 \\
CFA & $.77^{\mathrm{c}}$ & $.98^{\mathrm{c}}$ & 1.11 & 1.26 & .84 \\
CFAF & $.70^{\mathrm{c}}$ & $1.13^{\mathrm{b}}$ & .98 & 1.26 & .97 \\
\hline
\end{tabular}

${ }^{\prime}$ Contour $=$ untreated native range; $\mathbf{C F A}=$ contour furrowed and interseeded with alfalfa; CFAF $=$ contour furrowed, interseeded with alfalfa, and $112 \mathrm{~kg} \mathrm{~N}$ and $15 \mathrm{~kg} P$ applied per ha.

${ }_{2 b, c}$ Means within years with unlike superscripts differ $(R<.05)$.

Table 2. Composition of forages (percent) on untreated and contour-furrowed rangeland.

\begin{tabular}{|c|c|c|c|c|c|c|}
\hline \multirow[b]{2}{*}{ Forage class } & \multirow[b]{2}{*}{ Treatment ${ }^{1}$} & \multicolumn{4}{|c|}{ Year } & \multirow[b]{2}{*}{ Mean } \\
\hline & & 1975 & 1976 & 1977 & 1978 & \\
\hline Grasses \& sedges & $\begin{array}{l}\text { Control } \\
\text { CFA } \\
\text { CFAF }\end{array}$ & $\begin{array}{l}98.2 \\
46.9 \\
49.5\end{array}$ & $\begin{array}{r}100.0 \\
39.8 \\
51.2\end{array}$ & $\begin{array}{l}99.7 \\
60.1 \\
43.8\end{array}$ & $\begin{array}{l}90.0 \\
71.5 \\
66.5\end{array}$ & $\begin{array}{l}97.0 \\
54.6 \\
52.8\end{array}$ \\
\hline Forbs & $\begin{array}{l}\text { Control } \\
\text { CFA } \\
\text { CFAF }\end{array}$ & $\begin{array}{r}1.8 \\
3.0 \\
.9\end{array}$ & $\begin{array}{l}0 \\
1.7 \\
2.5\end{array}$ & $\begin{array}{r}.3 \\
5.3 \\
2.0\end{array}$ & $\begin{array}{r}10.0 \\
5.1 \\
5.6\end{array}$ & $\begin{array}{l}3.0 \\
3.8 \\
2.8\end{array}$ \\
\hline Shrubs & $\begin{array}{l}\text { Control } \\
\text { CFA } \\
\text { CFAF }\end{array}$ & $0^{0} .6$ & $\begin{array}{l}0 \\
0 \\
0\end{array}$ & $\begin{array}{l}0 \\
0 \\
0\end{array}$ & $\begin{array}{l}0 \\
2.5 \\
.8\end{array}$ & $\begin{array}{l}0 \\
.8 \\
.2\end{array}$ \\
\hline Alfalfa & $\begin{array}{l}\text { Control } \\
\text { CFA } \\
\text { CFAF }\end{array}$ & $\begin{array}{c}0 \\
49.5 \\
49.6\end{array}$ & $\begin{array}{c}0 \\
58.5 \\
46.3\end{array}$ & $\begin{array}{c}0 \\
34.6 \\
54.2\end{array}$ & $\begin{array}{c}0 \\
20.9 \\
27.1\end{array}$ & $\begin{array}{c}0 \\
40.9 \\
44.3\end{array}$ \\
\hline
\end{tabular}

Control $=$ untreated rangeland; $\mathrm{CFA}=$ contour-furrowed rangeland interseeded with alfalfa $; \mathrm{CFAF}=$ contour-furrowed rangeland interseeded with alfalfa with $112 \mathrm{~kg} \mathrm{~N}$ and $15 \mathrm{~kg} P$ applied per hectare. 
Table 4. Beef production (total gain, $\mathrm{kg} / \mathrm{ha}$ ) on native range (control) or on contour-furrowed range interseeded with alfalfa (CFA) and with fertilizer added (CFAF)

\begin{tabular}{|c|c|c|c|c|c|c|c|c|c|c|c|c|}
\hline \multirow{2}{*}{$\begin{array}{l}\text { Year: } \\
\text { Item: }\end{array}$} & \multicolumn{2}{|c|}{1974} & \multicolumn{2}{|c|}{1975} & \multicolumn{2}{|c|}{1976} & \multicolumn{2}{|c|}{1977} & \multicolumn{2}{|c|}{1978} & \multicolumn{2}{|c|}{$1974-1978$} \\
\hline & $\begin{array}{l}\text { Number } \\
\text { animals }\end{array}$ & $\begin{array}{l}\text { Total } \\
\text { gain }\end{array}$ & $\begin{array}{l}\text { Number } \\
\text { animals }\end{array}$ & $\begin{array}{l}\text { Total } \\
\text { gain }\end{array}$ & $\begin{array}{l}\text { Number } \\
\text { a nimals }\end{array}$ & $\begin{array}{l}\text { Total } \\
\text { gain }\end{array}$ & $\begin{array}{l}\text { Number } \\
\text { animals }\end{array}$ & $\begin{array}{l}\text { Total } \\
\text { gain }\end{array}$ & $\begin{array}{l}\text { Number } \\
\text { animals }\end{array}$ & $\begin{array}{l}\text { Total } \\
\text { gain }\end{array}$ & $\begin{array}{l}\text { Number } \\
\text { animals }\end{array}$ & $\begin{array}{l}\text { Total } \\
\text { gain }\end{array}$ \\
\hline & \multicolumn{2}{|c|}{$5 / 10-7 / 10$} & \multicolumn{2}{|c|}{$5 / 27-8 / 8$} & \multicolumn{2}{|c|}{$5 / 14-7 / 12$} & \multicolumn{2}{|c|}{$5 / 20-6 / 17$} & \multicolumn{2}{|c|}{$5 / 22-7 / 17$} & & \\
\hline \multicolumn{13}{|c|}{ Treatments } \\
\hline $\begin{array}{l}\text { Control } \\
\text { CFA } \\
\text { CFAF }\end{array}$ & $\begin{array}{r}6 \\
18 \\
18\end{array}$ & $\begin{array}{l}26 \\
52 \\
47\end{array}$ & $\begin{array}{r}6 \\
13 \\
13\end{array}$ & $\begin{array}{l}33 \\
57 \\
66\end{array}$ & $\begin{array}{r}6 \\
12 \\
15\end{array}$ & $\begin{array}{l}20 \\
49 \\
53\end{array}$ & $\begin{array}{r}6 \\
11 \\
12\end{array}$ & $\begin{array}{l}12 \\
24 \\
26\end{array}$ & $\begin{array}{r}6 \\
12 \\
13\end{array}$ & $\begin{array}{l}22 \\
35 \\
44\end{array}$ & $\begin{array}{l}30 \\
66 \\
71\end{array}$ & $\begin{array}{l}113 \\
217 \\
236\end{array}$ \\
\hline
\end{tabular}

'Fertilized with $112 \mathrm{~kg} \mathrm{~N}$ and $19 \mathrm{~kg} \mathrm{P} / \mathrm{ha}$.

Mean annual forage production for the 4 years for which production data are available was $603,1,305$, and $1,658 \mathrm{~kg} /$ ha for the control, CFA and CFAF, respectively (Table 1). If utilization were held at $50 \%$ on all treatments, stocking the CFA at double the level of the control appears to be an appropriate adjustment. By the same line of reasoning, CFAF should be able to handle about $25 \%$ more than CFA. An area that deserves further investigation is the degree of utilization that can be imposed on the CFA and CFAF treatments without adversely affecting stand maintenance. In some years, $50 \%$ utilization on the CFA or CFAF pastures left more residue following grazing than the total production on the control pasture. How much of that residue that can or should be utilized remains to be determined. Forage production was more variable on the CFA and CFAF pastures than on the control. Therefore, more flexibility in animal numbers would be desirable on contourfurrowed range than for untreated range to obtain optimum use of available forage.

No bloat problems from alfalfa consumption were observed, although blocks containing poloxalene were available to the animals on the CFA and CFAF pastures. Generally, alfalfa development had progressed to the pre-bloom or early bloom stage at the time cattle began grazing. Under conditions of this experiment, the health and vigor of the alfalfa stand did not appear to be adversely affected by grazing.

Some questions on the use of furrows interseeded with alfalfa that remain to be answered include: (1) What is the optimum time for grazing alfalfa seeded in contour furrows to maximize beef production and still maintain a vigorous stand of alfalfa and native species? (2) How long and at what level will contour furrows continue to produce forage at acceptable levels? (3) How can alfalfa in contour furrows be best managed for different classes of livestock? (4) What indicators might be used to predict forage availability prior to a predetermined turn-on date.

The results of this work showed that interseeding alfalfa into contour furrows produced forage sufficient to double beef production per unit of area as compared to untreated native range. With the exception of the first year, rate of gain differences among treatments were small, so beef production was primarily a function of stocking rate.

\section{Literature Cited}

Caprio, J.M., R.D. Snyder, and G.D. Grunwald. 1980. Precipitation probabilities in Montana. Montana Agr. Exp. Sta. Bull. 712.

Neff, Earl L. 1973. Water storage capacity of contour furrows in Montana. J. Range Manage. 26:298-301.

Neff, Earl L., and J.R. Wight. 1977. Overwinter soil water recharge and herbage production as influenced by contour furrowing on eastern Montana rangelands. J. Range Manage. 30:193-195.

Solseth, R.J., J.R. Wight, and J.K. Aase. 1974. Improvement of panspot (Solonetzic) range sites by contour furrowing. J. Range Manage. 27:107110.

Steel, R.G.D., and J.H. Torrie. 1960. Principles and Procedures of Statistics. McGraw-Hill, Inc., New York.

U.S. Department of Agriculture, Soil Conservation Service. 1971. Technican's guide to range sites, condition classes and recommended stocking rates in the soil districts of the sedimentary plains of Montana, 10-14" precipitation zone. Montana SCS State Office, Technical Guide.

U.S. Department of Commerce, National Oceanic and Atmospheric Administration, 1979. Climatological Data Annual Summary, Montana. Vol. 82. p. 5.

Wight, J.R. 1976. Range fertilization in the northern Great Plains. J. Range Manage. 26:180-185.

Wight, J.R., E.L. Neff, and R.J. Soiseth. 1978a. Vegetation response to contour furrowing. J. Range Manage. 31:97-101.

Wight, J.R., F.H. Siddoway, R.J. Kartchner, and J.L. Bishop. 1978b. Contour furrows seeded with grasses and legumes. Proc., 1st Int. Rangeland Cong. p. 643-644. 